Article

\title{
Soil-Biodegradable Plastic Mulches Undergo Minimal in-Soil Degradation in a Perennial Raspberry System after 18 Months
}

\author{
Huan Zhang ${ }^{1}\left(\mathbb{D}\right.$, Markus Flury $^{2}$, Carol Miles ${ }^{1}$, Hang Liu ${ }^{3}$ and Lisa DeVetter ${ }^{1, *(\mathbb{D})}$ \\ 1 Department of Horticulture, Northwestern Washington Research \& Extension Center, Washington State \\ University, Mount Vernon, WA 98273, USA; huan.zhang@wsu.edu (H.Z.); milesc@wsu.edu (C.M.) \\ 2 Department of Crop and Soil Sciences, Washington State University Puyallup Research \& Extension Center, \\ Puyallup, WA 98371, USA; flury@wsu.edu \\ 3 Department of Apparel, Merchandising, Design and Textiles, Washington State University, Pullman, \\ WA 99164, USA; hangliu@wsu.edu \\ * Correspondence: lisa.devetter@wsu.edu
}

Received: 19 July 2020; Accepted: 18 August 2020; Published: 20 August 2020

\begin{abstract}
Soil-biodegradable plastic mulches (BDMs) are made from biodegradable materials that can be bio-based, synthetic, or a blend of these two types of polymers, which are designed to degrade in soil through microbial activities. The purpose of BDMs is to reduce agricultural plastic waste by replacing polyethylene (PE) mulch, which is not biodegradable. Most studies have evaluated the breakdown of BDMs within annual production systems, but knowledge of BDM breakdown in perennial systems is limited. The objective of this study was to evaluate the deterioration and degradation of BDMs in a commercial red raspberry (Rubus ideaus L.) production system. Deterioration was low ( $\leq 11 \%$ percent soil exposure; PSE) for all mulches until October 2017 (five months after transplanting, MAT). By March 2018 (10 MAT), deterioration reached 91\% for BDMs but remained low for PE mulch (4\%). Mechanical strength also was lower for BDMs than PE mulch. In a soil burial test in the raspberry field, $91 \%$ of the BDM area remained after 18 months. In-soil BDM degradation was minimal, although the PSE was high. Since mulch is only applied once in a perennial crop production system, and the lifespan of the planting may be three or more years, it is worth exploring the long-term degradation of BDMs in perennial cropping systems across diverse environments.
\end{abstract}

Keywords: polyethylene mulch; degradation; deterioration; mechanical property; mesh bag study

\section{Introduction}

Agricultural plastic mulch, primarily made of polyethylene (PE), has been used widely in agriculture since the 1950s [1]. Plastic mulch provides multiple benefits, such as suppressed weed growth, decreased use of herbicides, and increased water-use efficiency and crop yield. Globally, the mulch film market has an annual projected growth rate of $7.4 \%$ from 2018 to 2026 and an estimated value of $\sim 4.3$ billion US dollars in 2019 [2]. In China, PE mulch was applied to approximately 20 million ha of agricultural land in 2011 [3]. In North America, it was estimated that approximately 115,000 tons of PE mulch was used in 2016, and the estimated use in 2020 is 134,000 tons [4].

The continued use of PE mulch imposes two important challenges: (1) PE mulch is difficult to recycle, because its contamination with soil and plant debris (up to $50 \%$ by weight) has led to a lack of viable recycling programs, and (2) PE mulch is nonbiodegradable (predicted to remain in the environment up to 300 years) due to polyethylene chemical bonds being virtually resistant to microbial breakdown [1,5-8]. Therefore, most agricultural PE mulch is stockpiled on-site, landfilled, or burned, which creates environmental problems [1,9]. In addition, PE mulch is seldom completely removed from 
the field, and remaining PE mulch fragments can impair soil chemically, physically, and biologically properties [10]. A promising and potential alternative to PE mulch is soil-biodegradable plastic mulch (BDM) that is designed to biodegrade at least $90 \%$, as assessed by the conversion of carbon from biodegradable polymers to $\mathrm{CO}_{2}$ within two years by naturally occurring soil microorganisms in accordance with a laboratory test [11]. Biodegradable polymers can be bio-based or synthetic (e.g., derived from fossil fuels), with bio-based polymers tending to have higher rates of biodegradation than synthetic polymers [12]. The EN 17033 is the only testing regime for BDMs at the time of writing this paper and is used to distinguish BDMs from oxodegradable plastic mulches, which fragment to nonbiodegradable small mulch pieces (predominantly PE mulch). It is also important to note that BDMs are designed and advertised to be tilled into soil after crop production, which reduces plastic waste generation. However, at present in the USA, manufacturers are not required to test mulches for biodegradability under agricultural field conditions. Consequently, field studies, including the one reported in this paper, use the term "BDM" to refer to products that are advertised as soil-biodegradable, but this does not imply these mulches have been tested and found to be at least $90 \%$ biodegradable in all agricultural settings and soil conditions.

There are many reviews describing the breakdown of BDMs, which is impacted by many factors such as water, oxygen, temperature, mulch thickness, and microbial community size and composition [1,12-14]. In this paper, the breakdown of BDMs is defined as starting with deterioration on the surfaces of raised beds, followed by both additional in-soil deterioration and biodegradation [15]. Deterioration primarily consists of abiotic forces such as weather-induced damage (e.g., sunlight, wind, or temperature) of the BDM, causing it to weaken and fragment $[14,16]$. Biodegradation involves both abiotic and biotic factors. Biotic factors encompass naturally occurring microorganisms that can use the molecules in BDM in their metabolism to produce carbon dioxide, water, and microbial biomass $[11,17]$. Therefore, the degradation of BDMs can maintain or reduce the accumulation of plastics in the environment.

In the past decade, researchers have quantified the deterioration of BDMs in annual vegetable and strawberry (Fragaria $\times$ ananassa L.) production settings using semi-quantitative measurements, such as percent soil exposure (PSE) [18-23]. Cowan et al. [18] demonstrated, however, that PSE measurements are not a measure of degradation. To measure the degradation of BDMs, Calmon et al. [24] developed an in situ burial test. This test involved measuring the visible mulch surface area reduction as an estimate for degradation. The in situ burial test showed that degradation over a 24-month period was lowest in a Mediterranean climate $(\sim 10 \%)$ and highest in a continental climate ( $80-90 \%)$, whereas it was intermediate in an oceanic climate. Li et al. [25] used a similar method to quantify the area loss of four different BDMs following tomato (Solanum lycopersicum L.) productions at three locations in the USA. Degradation varied across the three locations 24 months post-mulch burial, with the highest degradation $(>97 \%)$ in a humid continental climate location with a warm soil, high air temperature, and a high abundance of fungi relative to Mediterranean and subtropical climates.

These studies advance the nascent knowledge of BDM performance and degradation in annual production systems where BDMs are tilled into the soil after a single growing season and the soil is tilled several times each year thereafter. In a perennial system, however, mulch stays in place longer; thus, there is more environmental weathering of the mulch before it is incorporated into the soil. Therefore, the degradation of a BDM in annual and perennial systems might differ due to differences in physical integrity at the time of soil incorporation. Tachibana et al. [26] were the first to study the degradation of BDMs in a perennial system (orange (Citrus reticulata L.)). Each BDM in their study consisted of different ratios of polylactic acid (PLA); chemically modified starch (e.g., derived from corn (Zea mays L.), sugar beets (Beta vulgaris L. subsp. vulgaris), switchgrass (Panicum virgatum L.), and/or sugarcane (Saccharum officinarum L.)); and poly(butylene adipate-co-terephthalate) (PBAT) [7]. It was found that BDM containing more chemically modified starch degraded rapidly on the soil surface after four months, whereas BDMs that contained more PLA and PBAT degraded little. However, multi-year studies are needed to assess the degradation of BDM in perennial systems. 
To our knowledge, this study is the first study to evaluate BDM deterioration and degradation over multiple years in a perennial fruit production system. The specific objective of this study was to evaluate the deterioration and degradation of BDMs using both semi-quantitative (PSE) and quantitative (mulch mechanical properties and digital image analysis) methods of assessment. Floricane red raspberry (Rubus ideaus L.) is used here as a model perennial crop, because it has a growing cycle of six or more years, and growers are increasingly using plastic mulch due to horticultural benefits [23,27].

\section{Materials and Methods}

\subsection{Experimental Location and Design}

The study was carried out in a commercial raspberry farm in Lynden, WA, USA ( $48^{\circ} 58^{\prime} 06^{\prime \prime} \mathrm{N}$, $122^{\circ} 25^{\prime} 30^{\prime \prime}$ W; $33 \mathrm{~m}$ above sea level) from 2017 to 2019 . The site has a Lynden sandy loam, classified as a Podzol (FAO), or a sandy, mixed, mesic Typic Haplorthods $[28,29]$. The experimental design was a randomized complete block with five mulch treatments (one PE mulch and four BDMs; Table 1) replicated 5 times. Blocking was done across rows to control for soil variations in texture. Each plot was 36-m-long and spaced $3 \mathrm{~m}$ center-to-center. The mulches were chosen based on suggestions provided by mulch manufactures for this production system combined with preliminary studies on commercial raspberry farms (DeVetter and Honcoop, unpublished data). All mulches are commercially available, and the primary biodegradable ingredient of the BDMs was PBAT, with PLA or starch as a co-component. Two different thicknesses of BDMs (Organix Solutions, Bloomington, MN, USA and PolyExpert Inc., Laval, QC, Canada) were used, 12.7 and $15.2 \mu \mathrm{m}$, to test the suitability for perennial crop production. Additional mulch polymer properties are provided in Hayes et al. [30].

Table 1. Polyethylene (PE) and biodegradable plastic mulch (BASF and Novamont) treatments applied to tissue culture "Wake ${ }^{\mathrm{TM}}$ Field" raspberry in May 2017 in Northwestern WA, USA.

\begin{tabular}{cccc}
\hline Mulch Product $^{\mathbf{z}}$ & $\begin{array}{c}\text { Thickness } \\
(\boldsymbol{\mu \mathbf { m } )}\end{array}$ & Converter & Key Product Ingredient(s) $\mathbf{y}$ \\
\hline BASF 0.5 & 12.7 & Organix Solutions, Bloomington, MN, USA & PLA + PBAT z \\
BASF 0.6 & 15.2 & Organix Solutions, Bloomington, MN, USA & PLA + PBAT \\
Novamont 0.5 & 12.7 & PolyExpert Inc., Laval, QC, Canada & Starch-based, PBAT copolyester \\
Novamont 0.6 & 15.2 & PolyExpert Inc., Laval, QC, Canada & Starch-based, PBAT copolyester \\
PE & 25.4 & FilmTech, LLC., Stanley, WI, USA & Polyethylene \\
\hline
\end{tabular}

${ }^{\mathrm{z}}$ BASF and Novamont mulch treatments, manufactured by Organix Solutions and PolyExpert Inc., respectively, are biodegradable based on EN 17033 (tests biodegradability in a laboratory setting with an agricultural or forestry soil) and have TUV OK Soil Biodegradable certification. BASF 0.5 and BASF 0.6 are made of the same feedstock but with different thicknesses $(0.5=0.5 \mathrm{mil}$ and $0.6=0.6 \mathrm{mil})$. Novamont 0.5 and Novamont 0.6 are made of the same feedstock but with different thicknesses $\left(0.5=0.5\right.$ mil and $0.6=0.6$ mil). ${ }^{y}$ The specific content of each polymer is not provided by the manufacturers due to proprietary reasons. ${ }^{\mathrm{z}} \mathrm{PLA}=$ polylactic acid and PBAT $=$ poly $($ butylene adipate-co-terephthalate).

\subsection{Weather and Soil Characteristics}

The field site has a warm Mediterranean climate (Csb) [31]. Annual air and soil temperature at $20 \mathrm{~cm}$ depth, solar radiation, relative humidity, total rainfall, and wind speed were collected from the Washington State University Nooksack AgWeatherNet station, located $8 \mathrm{~km}$ east of the study site. From April 2018 to October 2019, when BDM treatments were buried in mesh bags within the plots, the average soil temperature and moisture were measured (5 TM sensors; Meter Group, Inc., Pullman, WA, USA) and recorded (EM50 Digital loggers; Meter Group, Inc.) at $10 \mathrm{~cm}$ depth every $15 \mathrm{~min}$ in four BDM treatments in the third replicate. PE mulch was removed in March 2018 and was not included in the mesh bag test (see "mesh bag samples and burial" methods). The sensors were buried next to and at the same level as the mesh bags. 


\subsection{Field History, Mulch Laying, and Field Maintenance}

In Sept. 2016, a commercial fumigation company (Trident Agriculture Products, Woodland, WA, USA) broadcast fumigated the entire field at the rate of $54 \mathrm{~L} \cdot \mathrm{ha}^{-1}$ (Telone C-35 ${ }^{\circledR} ; 65 \%$ 1,3-dichloropropene and 35\% chloropicrin; Dow Agrosciences, Indianapolis, IN, USA). Fumigation was done to manage root lesion nematode (Pratylenchus penetrans (Cobb) Filipjev and Schuurmans Stekhoven). After fumigation, the entire field was seeded with a winter wheat (Triticum aestivum L.) cover crop. In May 2017, raised beds were formed 0.36-m-high and 0.91-m and 1.0-m-wide at the top and bottom, respectively. Mulches were applied 1 week later, on 17 May 2017, and were laid over the raised beds using a custom-built flat-bed layer. Simultaneously, drip tape (emitter spacing $61 \mathrm{~cm}$, BlueLine PC Clipperline, TORO, Bloomington, MN, USA) was placed slightly off-center on the bed. Immediately after mulch-laying, a customized dibble was used to create planting holes 10-cm-wide, 7.5-cm-deep, and spaced 66- $\mathrm{cm}$-apart along the row center. Tissue culture "Wake ${ }^{\mathrm{TM}}$ Field" raspberry transplants were planted on the same day in the raised beds. Two months after mulch-laying, wooden trellising posts to support raspberry plant growth were installed.

\subsection{Mulch Deterioration}

Mulch deterioration during the growing season was measured as percent soil exposure (PSE), which is an indicator of mulch functionality and performance. PSE was visually assessed by the same person from May 2017 to March 2018 in a 1- $\mathrm{m}^{2}$-area in the center of each plot twice per month (approximately the 15th and 30th of each month). A PSE of $0 \%$ represented a completely intact mulch, whereas a rating of $100 \%$ represented fully exposed soil. Ratings were made in $1 \%$ increments until $20 \%$ exposure, and then, $5 \%$ increments were used thereafter [18]. Mulch mechanical properties were assessed on environmentally weathered mulches collected from the field on 20 January 2018, approximately 8 months after mulch application. A $1-\mathrm{m}^{2}$ mulch sample was collected from the raised bed surface of each plot in the first three replicates. Within $24 \mathrm{~h}$ of mulch collection, mulch samples were cleaned by gently showering the surface with tap water to remove soil. Next, mulch samples were air-dried for $24 \mathrm{~h}$ at ambient air temperature $\left(25^{\circ} \mathrm{C}\right)$, then shipped to the Washington State University Textiles Laboratory in Pullman, WA, USA for assessment. Three specimens (2.5-cm-wide and 15-cm-long each) in each the machine (along the mulch roll) and transverse (perpendicular to the mulch roll) directions were randomly cut from each mulch sample using a hydraulic press. Elongation (percent elongation at peak load; \%) and breaking force (peak load; measured in Newton, N) were measured (Instron 5565A; Instron; Norwood, MA, USA) in accordance to ASTM D5035-11 [32]. The distance between the two specimen holders of the tester, which is the effective testing length, was set at $75 \mathrm{~mm}$. Elongation is a measure of how much the material can stretch before breaking, and the breaking force indicates how much force is needed to pull apart the material.

\subsection{Mesh Bag Samples and Burial}

On 30 March 2018, one $15 \times 15$-cm weathered mulch sample was cut from the top of the raised bed in each BDM plot, placed in a labeled plastic bag, transported under ambient temperature conditions $\left(25^{\circ} \mathrm{C}\right)$ to Washington State University Northwestern Washington Research and Extension Center, and stored at $4{ }^{\circ} \mathrm{C}$. PE mulch was not included in the mesh bag study, because it is not biodegradable [33]. On the same day, soil was collected at a $0-10-\mathrm{cm}$ depth from the top of the raised bed of each respective plot using a shovel. Three soil samples from each plot were bulked, thoroughly mixed, and stored at $4{ }^{\circ} \mathrm{C}$ until mesh bag preparation.

On 11 April 2018, the mulch samples were gently cleaned with wet paper towels to remove adhered soil, then cut into three $5 \times 5$-cm mulch samples. Each $5 \times 5$-cm mulch sample was placed into a white nylon mesh bag (1-mm mesh opening; Industrial Netting, Inc., Minneapolis, MN, USA) measuring $10 \times 14 \mathrm{~cm}$. In each bag, the mulch sample was sandwiched between approximately $100 \mathrm{~g}$ of soil from its respective plot, with soil evenly distributed on both sides of the mulch sample (50 $\mathrm{g}$ of 
soil per side). The open side of the mesh bag was folded and stapled with stainless-steel staples (Salco Inc, East Syracuse, NY, USA) so that the final size of each mesh bag was $10 \times 10 \mathrm{~cm}$. BASF 0.6 mulch was chosen as a no-soil mesh bag treatment (BASF 0.6NS) to assess whether including soil in the mesh bag would impact degradation. BASF $0.6 \mathrm{NS}$ mesh bags were assembled as described above, except no soil was added into the mesh bags.

Mesh bags with BDMs were stored at $4{ }^{\circ} \mathrm{C}$ for 1.5 days until placement in the field. Three mesh bags per plot (for three subsequent samplings) were attached together using a nylon string and buried in their respective plots, on the western side of the raised bed (beds oriented in a north-south direction). Mesh bags were placed parallel to the row at a depth of $10 \mathrm{~cm}$ in the area immediately adjacent to the south side of the region where PSE data were collected [34]. In BASF 0.6 plots, the mesh bags without soil (BASF 0.6NS) were attached together with a separate nylon string and buried in-line with the mesh bags that contained soil.

\subsection{Mesh Bag Collection, Cleaning, and Imaging}

Mulch degradation was assessed using a method similar to the ones described in Calmon et al. [24], Rasband [35], and Sintim et al. [34]. One buried mesh bag per plot, from north to south, was removed from the field every 6 months (18 October 2018, 18 April 2019, and 25 October 2019) and stored at $4{ }^{\circ} \mathrm{C}$ for no more than 4 days before cleaning and imaging. The stapled side of the mesh bag was cut open using scissors. Soil and mulch were removed and placed on a sieve $(1 \mathrm{~mm}$; Dual Manufacturing Co; Franklin Park, IL, USA). Mulch samples, including BASF 0.6NS, were gently washed using tap water and then air-dried. The mulch sample from each mesh bag was placed on white paper (Aspen 30; Boise Paper; Boise, ID, USA) to create a distinct contrast and covered with a transparent plastic sheet. A brush (2.4-mm Lauren ${ }^{\mathrm{TM}}$; Princeton Artist Brush Co.; Princeton, NJ, USA) was used to gently move the mulch corners so that the sample was laid flat to determine its real surface area. Two rulers (30-cm Westcott; Seneca Falls, NY, USA) were placed parallel to two adjacent sides of the mulch sample for scale. A photograph (ELPH 180, Canon; Tokyo, Japan) of each mulch sample was taken, and the mulch area was calculated using ImageJ (National Institute of Health, Bethesda, MD, USA) with the Threshold Color plugin. Each image was uploaded separately for calibration and analysis. Each picture was analyzed three times, and the mean and standard deviation were calculated. The area of the mulch samples prior to burial (April 2018) was calculated based on the sample size $\left(5 \mathrm{~cm} \times 5 \mathrm{~cm}=25 \mathrm{~cm}^{2}\right)$ and was considered as a 100\% mulch area. The area of each mulch sample measured thereafter was relative to this amount.

\subsection{Statistical Analysis}

All data were analyzed with JMP 14.0.0 (SAS Institute, Cary, NC, USA). Mulch-breaking force and remaining mulch area in the mesh bags were analyzed as a randomized complete block design by analysis of variance (ANOVA), while mulch elongation data were log-transformed before being analyzed by ANOVA. A Tukey's honest significant difference test was used for comparisons at a significance level of $p=0.05$. PSE data were analyzed with a Wilcoxon nonparametric test, and mean separations were performed with a Wilcoxon nonparametric multiple comparison procedure, because that data did not meet the assumptions of ANOVA. Nontransformed data and standard deviation are presented.

\section{Results}

\subsection{Environmental Data}

Raspberry plants begin actively growing in April in this region, and visible growth stops in October. The climate data recorded for the experimental period is summarized in Table 2 (WSU AgWeatherNet, 2020). The climate during the 2018 and 2019 growing seasons (April through October) was very similar and, on average, was: $14.3^{\circ} \mathrm{C}$ daily temperature, $20.1{ }^{\circ} \mathrm{C}$ daily maximum temperature, $9.0^{\circ} \mathrm{C}$ daily 
minimum temperature, $3084 \mathrm{MJ} \cdot \mathrm{m}^{2}$ solar radiation, $80 \%$ relative humidity $(\mathrm{RH})$, and $414-\mathrm{mm}$ total rainfall. During the winter (November 2018 through March 2019), the average daily temperature was $2.5^{\circ} \mathrm{C}$, while the $\mathrm{RH}(84 \%)$ and precipitation $(351 \mathrm{~mm})$ were very similar to the growing season. Most precipitation (78\%) occurred in October 2017 through February 2018, when the air temperature was $5.1^{\circ} \mathrm{C}$ on average. There were 78 days with wind speeds over $36 \mathrm{~km} \cdot \mathrm{h}^{-1}$ from May 2017 to February 2018; 33 of these days occurred from May to October 2017, and 45 days occurred from November 2017 to February 2018 (data not shown).

Soil temperature at a $10-\mathrm{cm}$-depth was similar for all mulch treatments during the entire study (data not shown). Average soil temperature was $15.0^{\circ} \mathrm{C}$ from April to October $2018,4.8^{\circ} \mathrm{C}$ from November 2018 to March 2019, and $15.0^{\circ} \mathrm{C}$ from April to October 2019 (Figure 1; Novamont 0.6 data was excluded from April to October 2018, because the sensor was accidently removed by a field worker). Average soil moisture at a 10-cm-depth for all mulch treatments was $0.20 \mathrm{~m}^{3} \cdot \mathrm{m}^{-3}$ (range was 0.18 to $0.24 \mathrm{~m}^{3} \cdot \mathrm{m}^{-3}$ ) from April to October 2018, $0.18 \mathrm{~m}^{3} \cdot \mathrm{m}^{-3}$ (range was 0.13 to $0.23 \mathrm{~m}^{3} \cdot \mathrm{m}^{-3}$ ) from November 2018 to March 2019, and $0.16 \mathrm{~m}^{3} \cdot \mathrm{m}^{-3}$ (range was 0.12 to $0.19 \mathrm{~m}^{3} \cdot \mathrm{m}^{-3}$ ) from April to October 2019 (Figure 1).
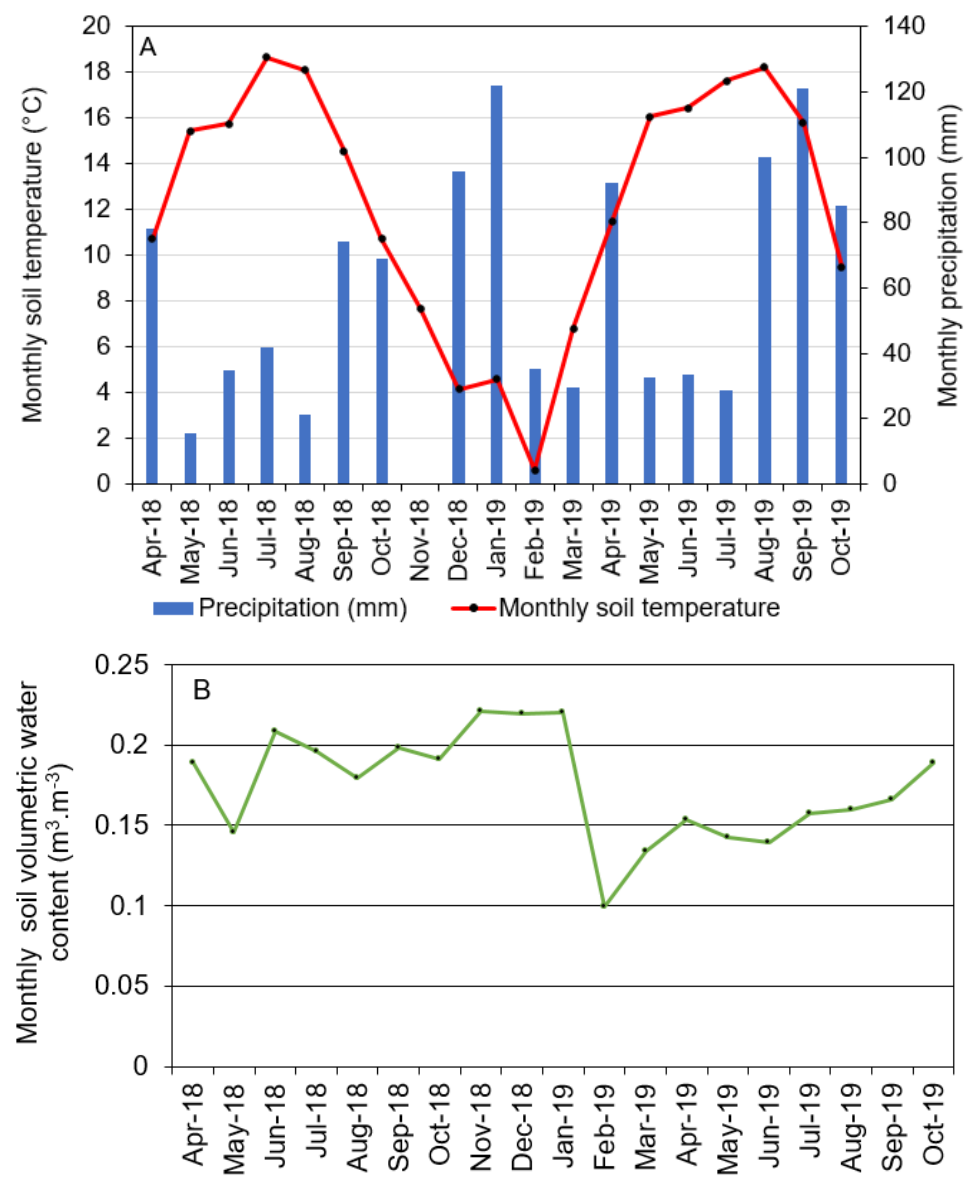

Figure 1. Monthly soil temperature $\left({ }^{\circ} \mathrm{C}\right)$ and precipitation $(\mathrm{A})$ and monthly volumetric water content (m3.m-3) (B) from April 2018 to October 2019 in a raspberry field. Soil sensors were installed at a depth of $10 \mathrm{~cm}$ in the third replicate of four BDM treatments; data were recorded every $15 \mathrm{~min}$, and the average was calculated for all treatments due to strong similarity. Monthly precipitation was taken from the Washington State University Nooksack AgWeatherNet Station located $8 \mathrm{~km}$ east of the study site. 
Table 2. Environmental data near the commercial raspberry field used in this study in Northwestern WA, USA in 2018 and 2019.

\begin{tabular}{cccc}
\hline Environmental Variables z & April-October & November & April-October \\
& $\mathbf{2 0 1 8}$ & 2018-March 2019 & 2019 \\
\hline Average daily air temperature $\left({ }^{\circ} \mathrm{C}\right)$ & 14.4 & 5.2 & 14.3 \\
Average daily maximum air temperature $\left({ }^{\circ} \mathrm{C}\right)$ & 20.5 & 10.5 & 19.8 \\
Average daily minimum air temperature $\left({ }^{\circ} \mathrm{C}\right)$ & 8.8 & 1.0 & 9.2 \\
Total solar radiation $(\mathrm{MJ} / \mathrm{m} 2)$ & 3278 & 891 & 2889 \\
Relative humidity $(\%)$ & 84 & 84 & 77 \\
Total rainfall $(\mathrm{mm})$ & 335 & 351 & 493 \\
\hline
\end{tabular}

${ }^{\mathrm{z}}$ Data summarized from Washington State University AgWeatherNet Station at Nooksack Station located $8 \mathrm{~km}$ east of the study site.

\subsection{Mulch Deterioration}

Just after application, the PSE did not differ among treatments and was $0 \%$ for PE mulch and less than 1\% for all BDMs ( $p=0.37$; Figures 2 and 3). From 14 July 2017 onwards, the PSE differed among treatments but was initially low for all treatments. For example, on 14 July 2017, the PSE for BASF 0.6 was $1.6 \%$ (similar to other BDM treatments), while the PSE for PE mulch was $0 \%(p=0.01$ ). The installation of the support posts on 15 July 2017 caused damage to all mulches in the form of small rips and tears. The PSE increased slowly until 27 October 2017 and was $13 \%$ on average for all BDMs and $1 \%$ for PE mulch $(p=0.01)$. The PSE increased rapidly thereafter for BDMs and, on 15 November 2017, exceeded 50\% for BASF 0.5 and Novamont $0.6(p=0.02)$ and exceeded $50 \%$ for BASF 0.6 and Novamont 0.5 on 16 January $2018(p=0.01)$. The PSE was similar for all four BDM treatments on 19 March 2018 (86\% on average) and reached 91\% on average on 30 March 2018 (the last date for the PSE assessment), while the PE mulch remained intact $(4 \%)(p=0.01)$.

The elongation (the amount of stretch before breaking) and breaking force (the amount of force exerted at the point of breaking) in machine and transverse directions differed among treatments (Table 3). In the machine direction, PE mulch had greater elongation (175\%) than all BDMs (11\% on average) $(p<0.0001)$. The breaking force was also greater for PE mulch $(7.7 \mathrm{~N})(p=0.002)$, while BASF 0.6 also had a high breaking force $(6.4 \mathrm{~N})$ but was statistically similar to BASF $0.5(4.9 \mathrm{~N})$. Novamont 0.5 and Novamont 0.6 had the lowest breaking forces ( $2.7 \mathrm{~N}$ on average). In the transverse direction, elongation was again greater for PE mulch $(261 \%)$ than for all BDMs (11\% on average) $(p<0.0001)$. The breaking force in the transverse direction was greatest for PE mulch $(5.6 \mathrm{~N})$ and BASF $0.6(4.8 \mathrm{~N})$, intermediate for BASF $0.5(3.1 \mathrm{~N})$ and Novamont $0.6(3.0 \mathrm{~N})$, and lowest for Novamont $0.5(1.5 \mathrm{~N})(p<0.0001)$.

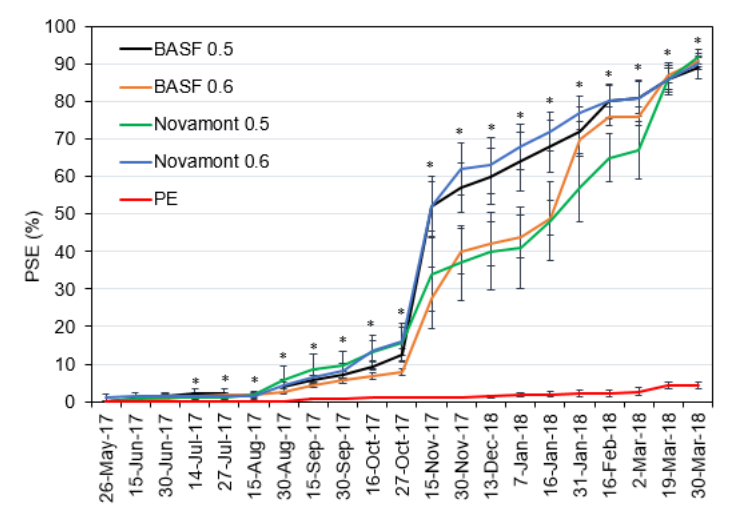

Figure 2. Percent soil exposure (PSE) of polyethylene (PE) and biodegradable plastic mulch (BASF and Novamont, where 0.5 and 0.6 indicate the film thicknesses: $0.5 \mathrm{mil}=12.7 \mu \mathrm{m}$ and $0.6 \mathrm{mil}=15.2 \mu \mathrm{m}$ ) treatments applied in a raspberry field in May 2017. * indicates significant difference at $p<0.05$ among treatments on the same date, using a nonparametric Wilcoxon multiple comparisons test at each time point. Values are the mean of 5 replications, and error bar is \pm standard error. 


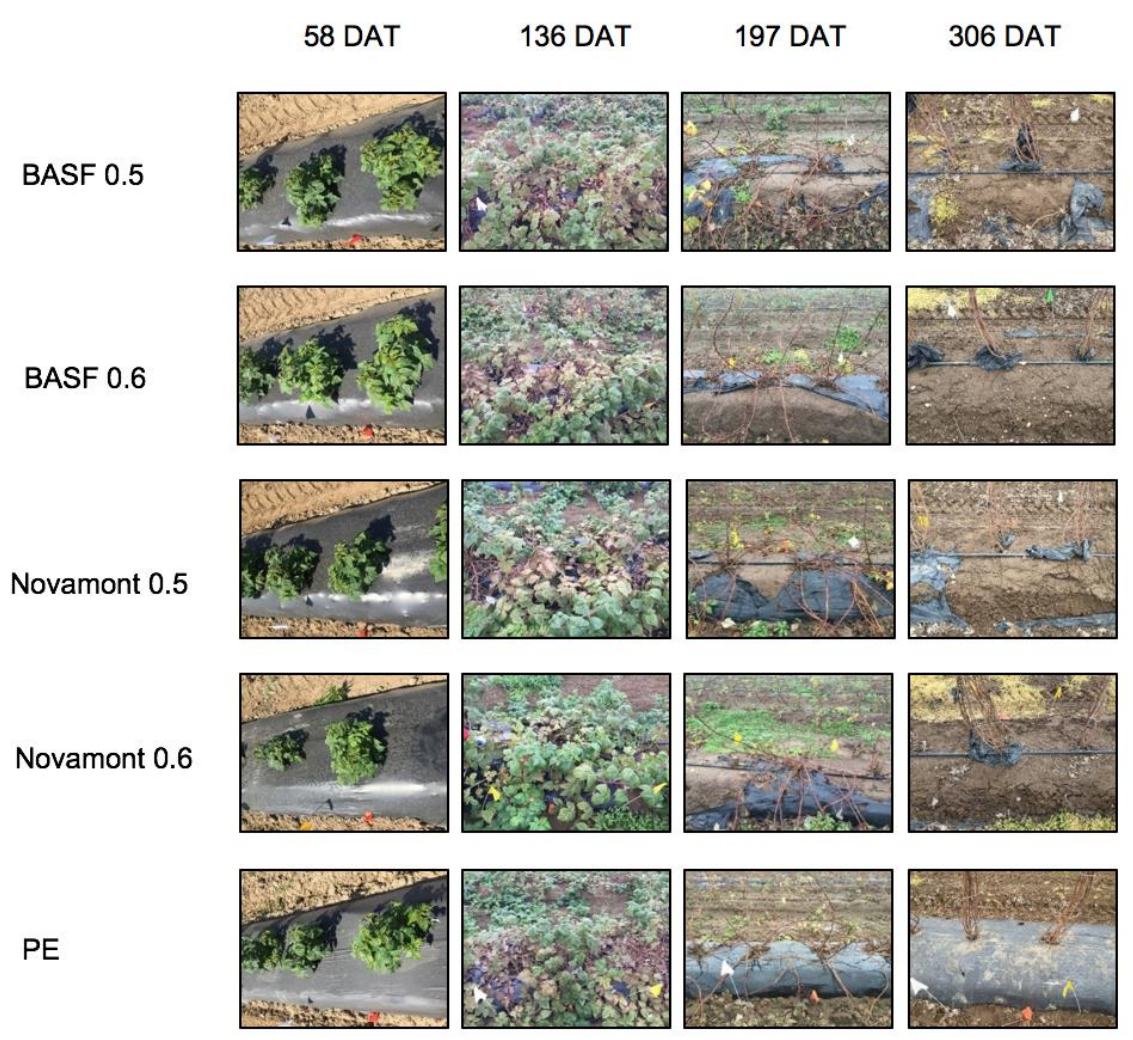

Figure 3. Appearance of polyethylene (PE) and biodegradable plastic (BASF and Novamont, where 0.5 and 0.6 indicate the film thicknesses: $0.5 \mathrm{mil}=12.7 \mu \mathrm{m}$ and $0.6 \mathrm{mil}=15.2 \mu \mathrm{m}$ ) treatments applied to raised beds in a raspberry field in May 2017 and photographed 58 days after transplanting (DAT) (14 July 2017), 136 DAT (30 Sept. 2017), 197 DAT (30 November 2017), and 306 DAT (19 March 2018).

Table 3. Elongation (\%) and breaking force $(\mathrm{N})$ in the machine and transverse directions for polyethylene (PE) and biodegradable plastic mulch (BASF and Novamont, where 0.5 and 0.6 indicate the film thicknesses: $0.5 \mathrm{mil}=12.7 \mu \mathrm{m}$ and $0.6 \mathrm{mil}=15.2 \mu \mathrm{m}$ ) treatments collected from the soil surface on 20 January 2018 (8 months of field exposure); all mulches were applied on raised beds in a raspberry field in May 2017.

\begin{tabular}{ccccc}
\hline & \multicolumn{2}{c}{ Machine Direction } & \multicolumn{2}{c}{ Transverse Direction } \\
\hline Treatment & Elongation (\%) & Breaking Force (N) & Elongation (\%) & Breaking Force (N) \\
\hline BASF 0.5 & $9.9 \pm 0.2 \mathrm{~b}^{\mathrm{z}}$ & $4.9 \pm 0.6 \mathrm{ab}$ & $9.5 \pm 0.6 \mathrm{~b}$ & $3.1 \pm 0.5 \mathrm{~b}$ \\
BASF 0.6 & $12.4 \pm 0.9 \mathrm{~b}$ & $6.4 \pm 0.6 \mathrm{a}$ & $12.5 \pm 0.8 \mathrm{~b}$ & $4.8 \pm 0.4 \mathrm{a}$ \\
Novamont 0.5 & $10.0 \pm 1.0 \mathrm{~b}$ & $2.5 \pm 0.4 \mathrm{~b}$ & $8.1 \pm 0.3 \mathrm{~b}$ & $1.5 \pm 0.1 \mathrm{c}$ \\
Novamont 0.6 & $12.4 \pm 4.1 \mathrm{~b}$ & $2.9 \pm 0.5 \mathrm{~b}$ & $12.2 \pm 0.9 \mathrm{~b}$ & $3.0 \pm 0.2 \mathrm{~b}$ \\
PE & $174.8 \pm 21.2 \mathrm{a}$ & $7.7 \pm 0.2 \mathrm{a}$ & $261.4 \pm 51.2 \mathrm{a}$ & $5.6 \pm 0.2 \mathrm{a}$ \\
\hline$p$-value & $<0.0001$ & 0.002 & $<0.0001$ & $<0.0001$ \\
\hline
\end{tabular}

${ }^{\mathrm{z}}$ Values are the mean of 3 replications \pm standard error. Means followed by the same letter within a column are not significantly different at $p<0.05$ using a means comparison with a Tukey's honestly significant difference test for all dates.

\subsection{Mesh Bag Mulch Area}

The amount of mulch remaining after burial in mesh bags did not differ due to treatments $(p=0.28$; Table 4). Although there was a difference in degradation due to sampling time $(p<0.0001)$, there was very little degradation of all treatments at all times (Table 4). The average remaining mulch area for all treatments was $97 \%$ at six months after burial (MAB), $90 \%$ at $12 \mathrm{MAB}$, and $91 \%$ at $18 \mathrm{MAB}(p=0.74$, 0.18 , and 0.38 , respectively; Figure 4$)$. There was very little variation ( $1 \%$ to $12 \%$ ) among the three Image J images. 


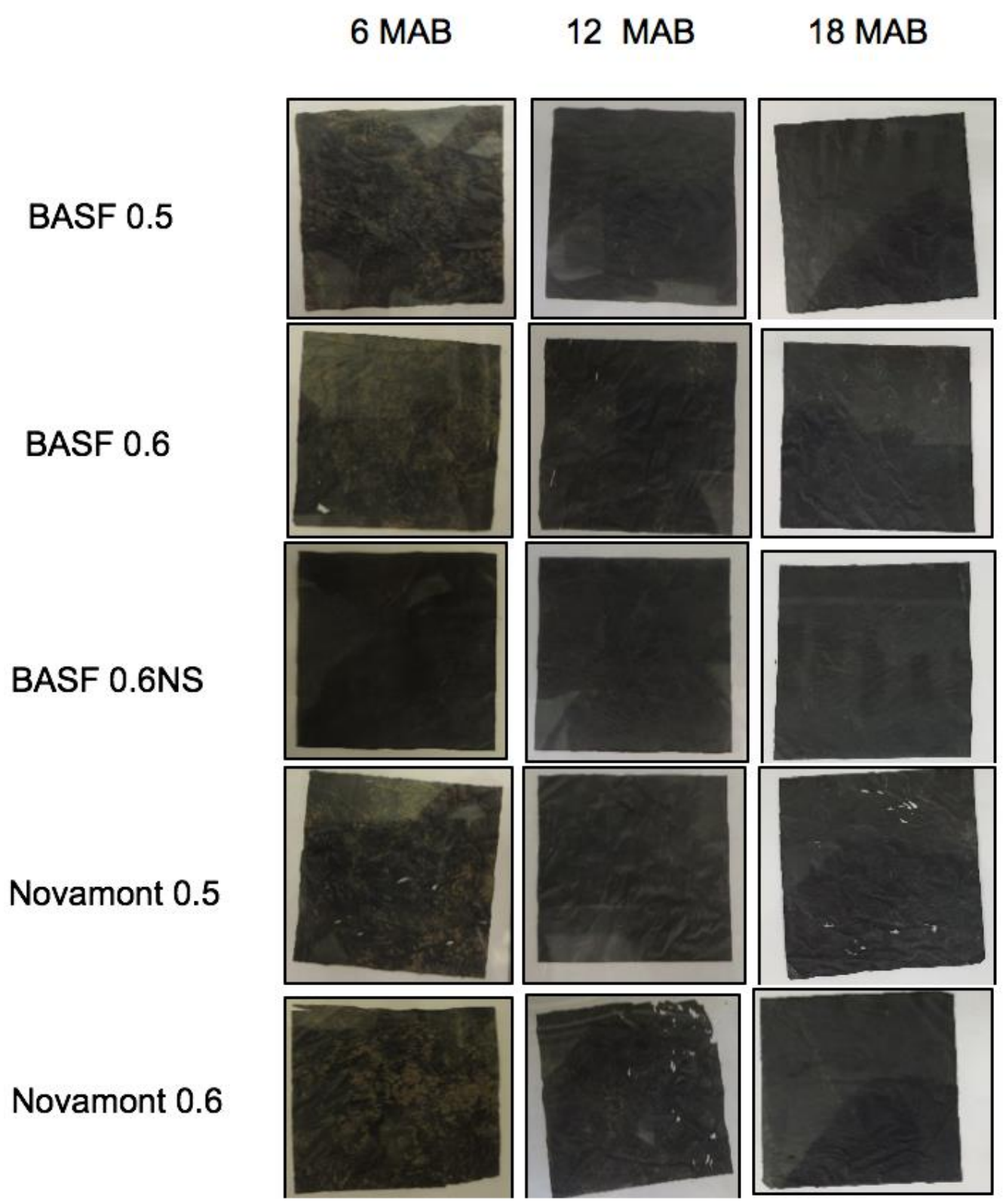

Figure 4. Biodegradable plastic mulch (BASF and Novamont, where 0.5 and 0.6 indicate the film thicknesses: $0.5 \mathrm{mil}=12.7 \mu \mathrm{m}$ and $0.6 \mathrm{mil}=15.2 \mu \mathrm{m}$ ) treatments removed from mesh bags 6 months after burial (MAB) (October 2018), 12 MAB (April 2019), and 18 MAB (October 2019). Prior to burial, mulches were weathered on top of a raised bed in a raspberry field for 11 months, then cut into squares measuring $25 \mathrm{~cm}^{2}$ and buried in April 2018 in their respective plots at a depth of $10 \mathrm{~cm}$. All treatments were buried with $100 \mathrm{~g}$ of soil in the mesh bags, except BASF $0.6 \mathrm{NS}$, which was buried without soil in the mesh bags. 
Table 4. Mulch area (\%) of biodegradable plastic mulch (BASF and Novamont, where 0.5 and 0.6 indicate the film thicknesses: $0.5 \mathrm{mil}=12.7 \mu \mathrm{m}$ and $0.6 \mathrm{mil}=15.2 \mu \mathrm{m})$ treatments prior to burial $(0)$ and collected 6, 12, and 18 months after burial (MAB). Burial was in April 2018 in raised beds of a raspberry field at a depth of $10 \mathrm{~cm}$.

\begin{tabular}{ccccc}
\hline \multicolumn{5}{c}{ Mulch area (\%) } \\
\hline Treatment $^{\mathbf{z}}$ & 0 MAB $^{\mathbf{y}}$ & $\mathbf{6}$ MAB & 12 MAB & 18 MAB \\
\hline BASF 0.5 & $100.0 \pm 0^{\mathbf{x}}$ & $95.6 \pm 0.8$ & $89.3 \pm 1.9$ & $92.0 \pm 1.7$ \\
BASF 0.6 & $100.0 \pm 0$ & $96.7 \pm 0.7$ & $96.4 \pm 1.8$ & $93.7 \pm 1.1$ \\
BASF 0.6NS & $100.0 \pm 0$ & $96.4 \pm 0.7$ & $95.1 \pm 1.3$ & $92.0 \pm 2.0$ \\
Novamont 0.5 & $100.0 \pm 0$ & $97.6 \pm 0.3$ & $82.3 \pm 7.0$ & $87.1 \pm 4.1$ \\
Novamont 0.6 & $100.0 \pm 0$ & $96.0 \pm 1.9$ & $84.9 \pm 5.6$ & $88.4 \pm 1.7$ \\
\hline p-value & 1 & 0.74 & 0.18 & 0.38
\end{tabular}

z All mulches were placed in mesh bags with $100 \mathrm{~g}$ of soil, except BASF 0.6NS, which had no soil in the mesh bags. ${ }^{y}$ Mulches were applied in a raspberry field in May 2017, collected in March 2018, and cut into squares measuring $25 \mathrm{~cm}^{2}$ for burial. Mulch area at $0 \mathrm{MAB}$ was not measured; the area was calculated based on the size of the mulch samples $\left(5 \mathrm{~cm} \times 5 \mathrm{~cm}=25 \mathrm{~cm}^{2}\right)$, which was considered as the $100 \%$ mulch area. ${ }^{x}$ Values are the mean of 5 replications \pm standard error.

\section{Discussion}

BDMs in this study did not remain intact on raspberry beds as long as PE mulch, which was expected. While BDMs began to deteriorate early in the growing season, deterioration was relatively low (13\% on average) until 27 October, and therefore, the overall weed control and yield were similar for PE and all BDM treatments in this study [27]. The first damage to BDMs occurred during mulch application, when plant debris from the previous raspberry planting (e.g., raspberry canes) and winter cover crop residue punctured the BDMs. No such damage was observed with PE mulch, similar as reported in a study by Zhang et al. [23]. Further damage to BDMs occurred during trellis post installations in July, but again, little damage occurred to PE mulch. This is because PE mulch can stretch more than BDM before it tears, and small holes in PE mulch do not enlarge much over time. The gradual increase in deterioration of BDMs after Aug. 2017 was likely due to raspberry growth. The raspberry cultivar used in this study has a trailing growth habit, and its prickles created many holes in the BDM when its canopy started covering and touching the mulch after July 2017 [27,36]. PE mulch again was not damaged much by the prickles and, thus, remained intact throughout this period. Indeed, PE mulch in this study remained completely intact until growers removed it in March 2018 to apply fertilizer and to prevent the mulch from restricting the raspberry primocane emergence. In contrast, BDMs had 90\% PSE by March 2018. Of note, some BDMs became attached to the raspberry canes by the prickles and were lifted up when the canes were trellised. This required the manual removal of the BDM for food safety concerns, to prevent BDM fragments from being harvested with the fruit during mechanical harvest.

Increased PSE for BDM treatments after Aug. 2017 was also likely due to fall precipitation (147 mm from Sept. to October 2017), as water is an important factor contributing to mulch deterioration and degradation [12]. In contrast, BDM deterioration remained relatively low from June to Aug. 2017, when there was $24 \mathrm{~mm}$ of precipitation and the RH was 77\%. The great increase in PSE for all BDM treatments that was observed between 27 October and 15 November 2017 was likely due to strong winds (15 days with maximum wind speed over $36 \mathrm{~km} \cdot \mathrm{h}^{-1}$ ). High winter winds are common for the production area where the study was carried out because of cold air outflows from the Fraser River Valley in British Columbia, Canada and was also observed in Zhang et al. [23]. BDM deterioration continued to increase in March 2018, because field workers who trained the canes stepped on the mulch, and also, mulch that adhered to canes was lifted from the soil surface. These results indicate that BDM is more susceptible than PE mulch to damage from cropping practices, as well as weathering.

BDMs are more susceptible to damage than PE mulch, because BDMs do not stretch as much, and less force is needed to tear BDMs (i.e., lower elongation and breaking force). This is a result of the 
feedstocks and thicknesses of BDMs. Many studies have shown that the bio-based feedstocks commonly used in BDMs can significantly reduce the mulch mechanical properties, including elongation and breaking force [37-39]. All BDMs in the current study contained up to $20 \%$ bio-based materials (i.e., PLA or starch-based materials). Further, in this study, the thickness of BDM treatments was only $50 \%$ to $60 \%$ that of the PE mulch. Thinner BDMs are preferred, because they degrade more quickly, and they are less expensive. Thus, it is expected that BDMs will have lower mechanical strength and, therefore, be more susceptible to weathering during exposure to environmental conditions, which is actually beneficial for biodegradation [12].

Mechanical properties are indirect indicators of mulch degradation, because the physical integrity of BDMs will deteriorate during the biodegradation process $[15,18,22]$. Although the BDMs in this study were made with the same feedstocks (PLA, PBAT, and starch) and by the same manufacturers as the BDMs used in Cowan et al. [18] and Zhang et al. [23], both the elongation and breaking force of BDMs were generally lower (100\% to $416 \%$ and $18 \%$ to $124 \%$, respectively) in the current study, likely due to differences in the lengths of environmental exposure. Cowan et al. [18] and Zhang et al. [23] sampled mulch treatments five months after application, and mulches were in place only during the summer season. In the current study, all mulch treatments were sampled approximately eight months after application, which included the summer plus three months of fall and winter. Greater environmental weathering occurred during the fall and winter due to increased wind and precipitation, which likely further reduced the mulch elongation and breaking force [12,15].

The low degradation after 18 months of burial in the soil may have been due to moderately warm air and soil temperature and soil moisture at the study site. Changes to the mulch physical integrity (deterioration) and chemical structure (degradation) occur to a lesser extent than at a site with higher air and soil temperature and soil moisture [40]. For example, Hayes et al. [15] reported that changes in mulch mechanical properties were less at Mount Vernon, WA, USA (50 miles south of the current study site), which has a Mediterranean climate (warm and dry summer), than at Knoxville, TN, USA, which has a subtropical climate. Calmon et al. [24] also found that BDM degradation mseasured as a surface area was the lowest $(\sim 10 \%)$ in a Mediterranean climate, similar to the results of the current study. Additionally, Li et al. [25] found similar results to the current study when different BDMs (BioAgri and BioTelo) were buried for 24 months in mesh bags with soil in the bags following tomato productions at three locations (Lubbock, TX, Knoxville, TN, and Mount Vernon, WA, USA). The amount of remaining mulch 24 months post-burial was greatest in WA ( $89 \%$ to $99 \%$ of their original areas) compared to the other two locations. BioAgri and BioTelo are both made of similar feedstocks as the Novamont mulches used in the current study. In another mesh bag study (no soil was included in the bags) that was established in WA and TN following an annual crop of pie pumpkin (Cucurbita pepo L.), BDMs made of similar feedstocks as the current study were more than $90 \%$ intact in WA after 18 months of soil burial and were $80 \%$ to $85 \%$ intact in TN [40]. In the current study, there was no difference in the BASF 0.6 mulch area between the two mesh bag methods (mesh bags with and without soil). This suggests that, at least for our experiments, the addition of soil into the mesh bags did not accelerate visual mulch degradation.

Both Novamont mulch treatments in this study had numerically greater degradation than the BASF mulch treatments that include PLA as a feedstock. This result is consistent with Tachibana et al. [26], Karamanlioglu and Robson [41], and Weng et al. [42]. Polymer chain mobility and the hydrolysis of ester linkages in PLA are reduced at temperatures commonly found in soil, which are lower than the glass transition temperature of PLA $\left(49.2^{\circ} \mathrm{C}\right)$ and much lower than the temperatures in composting conditions (up to approximately $80^{\circ} \mathrm{C}$ ) [34]. Consequently, the degradation rate at ambient temperatures commonly found in agricultural production systems is slower for mulches containing PLA [43-45]. Novamont and BASF BDM treatments include the feedstock PBAT, which is composed of both ester and aromatic chains of random chain lengths. The shorter chains have an increased degradation rate [46-48]. 
Air and soil temperatures and soil moisture can also impact the community composition of native fungi and bacteria in the soil, which are key to the biodegradation of BDMs [12]. Relatively low air and soil temperatures at this study site may inhibit the activity of plastic-degrading microorganisms and result in low degradation rates of BDMs [25]. Fungi in the family Trichocomaceae (e.g., genera Aspergillus and Penicillium) can effectively secrete plastic-degrading hydrolases that promote the degradation of BDMs [49,50]. Moore-Kucera et al. [51] extracted DNA from the surfaces of different mulches (including BioAgri and BioTelo) at three locations (Lubbock, TX, Knoxville, TN, and Mount Vernon, WA, USA) and found less diverse microorganisms in the Trichocomaceae family in WA compared to the other two warmer locations. This corresponds to the low biodegradation of BDMs that was found in Northwest WA, which also matches degradation results found by Li et al. [25] and Sintim et al. [40]. Moreover, the study site was broadcast fumigated eight months before mulch application, which has the potential to reduce key soil microbial populations that play important roles in the biodegradation of BDMs [12,52]. However, the burial of mesh bags occurred 20 months after fumigation. Soil fumigation effects tend to be short-lived in the raspberry system and provide $~ 6-12$ months of protection by suppressing soil pathogens, which allows crops to establish [53]. Soil fumigation alone does not drastically alter soil microbial communities based on previous studies done in this system, and microbial communities tend to be more responsive to seasonal effects than management practices [54]. Nonetheless, the effects of soil fumigation on BDM degradation deserve further study, but it seems unlikely that they would have a large effect based on the current knowledge of soil microbial communities in response to fumigation in raspberry systems.

\section{Conclusions}

To our knowledge, this study was the first to investigate the deterioration and degradation of BDMs in a perennial fruit production system. Although the PSE increased over time and mulch mechanical properties were lower for all BDMs than PE mulch, the BDMs used in this study did not have extensive visual degradation after 18 months of soil burial. The findings of this study are consistent with other studies with similar climates but in annual production systems. Potential factors that can slow down the degradation of BDMs in this climate include moderately warm soil and air temperatures, moderate summer precipitation, and the reduced abundance of plastic-degrading microorganisms that could be exacerbated by soil fumigation practices. However, mulch application is only required once in a raspberry planting system that has a lifespan of six or more years compared to annual mulch applications in vegetable or strawberry production systems. Thus, it is worthwhile to investigate changes in the mulch mechanical and chemical properties more rigorously and the long-term degradation of BDMs in perennial fruit production systems, as these production systems allow more time for mulch degradation. Moreover, unlike annual systems where growers mechanically incorporate BDMs into the soil after production, perennial systems do not permit easy mechanical incorporation due to the presence of the crop. The lack of incorporation through tillage could restrict degradation due to the presence of larger mulch fragments, which are slower to degrade. Therefore, future research should explore ways to incorporate BDMs into the soil to encourage microbial activities necessary for biodegradation or explore the application of products such as composts that can be surface-applied to accelerate degradation.

It is also important to note that the degradation of BDMs was estimated by quantifying changes in the mulch surface area, which is not a direct measurement of biodegradation. To better assess biodegradation, future research should monitor the carbon fate and $\mathrm{CO}_{2}$ evolution and, also, consider using gel exclusion chromatography, scanning electron microscopy, and Fourier-transform infrared spectroscopy to evaluate changes in the molecular level. Additionally, for a perennial system that may benefit from a longer mulching period, BDMs with different feedstocks and thicknesses could be experimented, along with characterizing their associated biodegradation rates. Lastly, we suggest that perennial fruit growers choose a proper BDM product that fits their production needs and climates. Consulting local extension specialists and checking mulch properties may be necessary. 
Author Contributions: Conceptualization, L.D., C.M. and M.F.; Data curation, H.Z. and H.L.; Formal analysis, H.Z.; Funding acquisition, L.D., C.M. and H.Z.; Investigation, L.D., C.M. and H.Z.; Methodology, H.Z., M.F., C.M., H.L. and L.D.; Project administration, L.D. and C.M.; Resources, L.D.; Supervision, L.D.; Writing-original draft, H.Z.; Writing-review \& editing, M.F., C.M., H.L. and L.D. All authors have read and agreed to the published version of the manuscript.

Funding: This work was funded by the Washington Red Raspberry Commission, Washington State Commission on Pesticide Registration, and Washington State Department of Agriculture Specialty Crop Block Grant program (K2525). This work was also supported by the United State Department of Agriculture National Institute of Food and Agriculture Hatch projects 1014919, 1017286, and 1014527.

Acknowledgments: We thank Ruth Watts of BASF and Dan Martens of Novamont for donating the soil-biodegradable mulches and providing technical advice. We also appreciate the technical assistance of Sean Watkinson, Weixin Gan, Brenda Mandrid, Ed Scheenstra, and Henry Sintim.

Conflicts of Interest: No potential conflicts of interest were reported by the authors.

\section{References}

1. Kasirajan, S.; Ngouajio, M. Polyethylene and biodegradable mulches for agricultural applications: A review. Agron. Sustain. Dev. 2012, 32, 501-529. [CrossRef]

2. Transparency Market Research Analysis. Agricultural Films Market. 2019. Available online: https: //www.transparencymarketresearch.com/mulch-films-market.html (accessed on 15 March 2020).

3. Liu, E.K.; He, H.Q.; Yan, C.R. 'White revolution' to 'white pollution': Agricultural plastic film mulch in China. Environ. Res. Lett. 2014, 9, 091001. [CrossRef]

4. MarketsandMarkets. Agricultural Films Market by Applications and Polymers—Global Trends and Forecasts to 2022; MarketsandMarkets Research Private Ltd.: Maharashtra, India, 2017.

5. Briassoulis, D.; Hiskakis, M.; Babou, E.; Antiohos, S.K.; Papadi, C. Experimental investigation of the quality characteristics of agricultural plastic wastes regarding their recycling and energy recovery potential. Waste Manag. 2012, 32, 1075-1090. [CrossRef] [PubMed]

6. Grossman, E. How can Agriculture Solve Its $\$ 5.87$ Billion Plastic Problem? 2015. Available online: https://www.greenbiz.com/article/how-can-agriculture-solve-its-1-billion-plastic-problem (accessed on 17 June 2015).

7. Miles, C.; DeVetter, L.; Ghimire, S.; Hayes, D.G. Suitability of biodegradable plastic mulches for organic and sustainable agricultural production systems. HortScience 2017, 52, 10-15. [CrossRef]

8. Ohtake, Y.; Kobayashi, T.; Asabe, H.; Murakami, N. Studies on biodegradation of LDPE-observation of LDPE films scattered in agricultural fields or in garden soil. Polym. Degrad. Stab. 1998, 60, 79-84. [CrossRef]

9. Goldberger, J.R.; Jones, R.E.; Miles, C.A.; Wallace, R.W.; Inglis, D.A. Barriers and bridges to the adoption of biodegradable plastic mulches for US specialty crop production. Renew. Agric. Food Syst. 2015, 30, 143-153. [CrossRef]

10. Chang-Rong, Y.; En-Ke, L.; Fan, S.; Liu, Q.; Liu, S.; Wen-Qing, H. Review of agricultural plastic mulching and its residual pollution and prevention measures in China. JARE 2014, 31, 95.

11. European Norms (EN). Plastics-Biodegradable Mulch Films for Use in Agriculture and Horticulture-Requirements and Test Methods. European Standard 17033; European Committee for Standardization: Brussels, Belgium, 2018.

12. Brodhagen, M.; Peyron, M.; Miles, C.; Inglis, D.A. Biodegradable plastic agricultural mulches and key features of microbial degradation. Appl. Microbiol. Biotechnol. 2015, 99, 1039-1056. [CrossRef]

13. Andrady, A.L. Assessment of environmental biodegradation of synthetic polymers. Macromol. J. Sci. Rev. Macromol. Chem. Phys. 1994, 3434, 25-76. [CrossRef]

14. Lucas, N.; Bienaime, C.; Belloy, C.; Queneudec, M.; Silvestre, F.; Nava-Saucedo, J.E. Polymer biodegradation: Mechanisms and estimation techniques. Chemosphere 2008, 73, 429-442. [CrossRef]

15. Hayes, D.G.; Wadsworth, L.C.; Sintim, H.Y.; Flury, M.; English, M.; Schaeffer, S.; Saxton, A.M. Effect of diverse weathering conditions on the physicochemical properties of biodegradable plastic mulches. Polym. Test. 2017, 62, 454-467. [CrossRef]

16. Chiellini, E.; Corti, A.; D'Antone, S.; Wiles, D.M. Oxo-biodegradable polymers: Present status and future perspectives. In Handbook of Biodegradable Polymers: Synthesis, Characterization and Applications; Lendlein, A., Sisson, A., Eds.; Wiley-VCH Verlag GmbH \& Co.: Weinheim, Germany, 2011; pp. 379-398. 
17. American Society for Testing and Materials (ASTM) D5988-18. Standard Test Method for Determining Aerobic Biodegradation of Plastic Materials in Soil; ASTM International: West Conshohocken, PA, USA, 2018.

18. Cowan, J.S.; Saxton, A.; Liu, H.; Leonas, K.; Inglis, D.; Miles, C. Visual assessments of biodegradable mulch deterioration are not indicative of mulch degradation. HortScience 2016, 51, 245-254. [CrossRef]

19. DeVetter, L.W.; Zhang, H.; Ghimire, S.; Watkinson, S.; Miles, C.A. Plastic biodegradable mulches reduce weeds and promote crop growth in day-neutral strawberry in western Washington. HortScience 2017, 52, 1700-1706. [CrossRef]

20. Ghimire, S.; Wszelaki, A.L.; Moore, J.C.; Inglis, D.A.; Miles, C. The use of biodegradable mulches in pie pumpkin crop production in two diverse climates. HortScience 2018, 53, 288-294. [CrossRef]

21. Miles, C.; Wallace, R.; Wszelaki, A.; Martin, J.; Cowan, J.; Walters, T.; Inglis, D. Deterioration of potentially biodegradable alternatives to black plastic mulch in three tomato production regions. HortScience 2012, 47, 1270-1277. [CrossRef]

22. Moreno, M.M.; González-Mora, S.; Villena, J.; Campos, J.A.; Moreno, C. Deterioration pattern of six biodegradable, potentially low-environmental impact mulches in field conditions. J. Environ. Manag. 2017, 200, 490-501. [CrossRef]

23. Zhang, H.; Miles, C.; Ghimire, S.; Benedict, C.; Zasada, I.; Liu, H.; DeVetter, L.W. Plastic mulches improved plant growth and suppressed weeds in late summer-planted floricane-fruiting raspberry. HortScience 2020, 55, 565-572. [CrossRef]

24. Calmon, A.; Guillaume, S.; Bellon-Maurel, V.; Feuilloley, P.; Silvestre, F. Evaluation of material biodegradability in real conditions-development of a burial test and an analysis methodology based on numerical vision. $J$. Polym. Environ. 1999, 7, 157-166. [CrossRef]

25. Li, C.; Moore-Kucera, J.; Miles, C.; Leonas, K.; Lee, J.; Corbin, A.; Inglis, D. Degradation of potentially biodegradable plastic mulch films at three diverse U.S. locations. Agroecol. Sustain. Food Syst. 2014, 38, 861-889. [CrossRef]

26. Tachibana, Y.; Maeda, T.; Ito, O.; Maeda, Y.; Kunioka, M. Utilization of a biodegradable mulch sheet produced from poly(lactic acid)/Ecoflex ${ }^{\circledR} /$ modified starch in Mandarin orange groves. Int. J. Mol. Sci. 2009, 10, 3599-3615. [CrossRef]

27. Zhang, H.; Miles, C.; Ghimire, S.; Benedict, C.; Zasada, I.; DeVetter, L. Polyethylene and biodegradable plastic mulches improve growth, yield, and weed management in floricane red raspberry. Sci. Hortic. 2019, 250, 371-379. [CrossRef]

28. Goldin, A. Soil Survey of Whatcom County Area, Washington; United States Department of Agriculture, Soil Conservation Service: Washington, DC, USA, 1992.

29. U.S. Department of Agriculture. The National List of Allowed and Prohibited Substances. U.S. Department of Agriculture Washington, DC. 2020. Available online: http://www.ecfr.gov/cgi-bin/text-idx?c=ecfr\&SID= 9874504b6f1025eb0e6b67cadf9d3b40\&rgn=div6\&view=text\&node=7:3.1.1.9.32.7\&idno=7\#sg7.3.205.g.sg0 (accessed on 29 March 2020).

30. Hayes, D.G.; Dharmalingam, S.; Wadsworth, L.C.; Leonas, K.K.; Miles, C.; Inglis, D.A. Biodegradable agricultural mulches derived from biopolymers. In Degradable Polymers and Materials: Principles and Practice, 2nd ed.; Khemani, K., Scholz, C., Eds.; American Chemical Society. Oxford Univ. Press, Inc.: Oxford, UK, 2012; pp. 201-223.

31. Peel, M.C.; Finlayson, B.L.; McMahon, T.A. Updated world map of the Köppen-Geiger climate classification. Hydrol. Earth Syst. Sci. 2007, 11, 1633-1644. [CrossRef]

32. ASTM D5305-11. Standard Test Method for Breaking Force and Elongation of Textile Fabrics (Strip Method); ASTM International: West Conshohocken, PA, USA, 2019.

33. Feuilloley, P.; Cesar, G.; Benguigui, L.; Grohens, Y.; Pillin, I.; Bewa, H.; Lefaux, S.; Jamal, M. Degradation of polyethylene designed for agricultural purposes. J. Polym. Environ. 2005, 13, 349-355. [CrossRef]

34. Sintim, H.Y.; Bary, A.I.; Hayes, D.G.; English, M.E.; Sean, M.; Miles, C.A.; Flury, M. Release of micro- and nanoparticles from biodegradable plastic during in situ composting. Sci. Total Environ. 2019, 675, 686-693. [CrossRef]

35. Rasband, W.S. ImageJ. U.S. National Institutes of Health, Bethesda, Maryland. Available online: http: //www.imagej.nih.gov/ij2014 (accessed on 15 December 2019). 
36. DeVetter, L.W.; Strik, B.C.; Moore, P.; Finn, C.; Dossett, M.; Sagili, R.; Miller, T.; Benedict, C.; Bryla, D.R.; Zasada, I.; et al. Commercial Red Raspberry Production in the Pacific Northwest; Washington State University Extension Publishing: Pullman, WA, USA, 2020.

37. Dharmalingam, S.; Hayes, D.G.; Wadsworth, L.C.; Dunlap, R.N. Analysis of the time course of degradation for fully biobased nonwoven agricultural mulches in compost-enriched soil. Text. Res. J. 2016, 86, 1343-1355. [CrossRef]

38. Mendes, J.F.; Paschoalin, R.; x Carmona, V.B.; Sena Neto, A.R.; Marques, A.C.P.; Marconcini, J.M.; Oliveira, J.E. Biodegradable polymer blends based on corn starch and thermoplastic chitosan processed by extrusion. Carbohydr. Polym. 2016, 137, 452-458. [CrossRef]

39. Thompson, A.A.; Samuelson, M.B.; Kadoma, I.; Soto-Cantu, E.; Drijber, R.; Wortman, S.E. Degradation rate of bio-based agricultural mulch is influenced by mulch composition and biostimulant application. J. Polym. Environ. 2019, 27, 498-509. [CrossRef]

40. Sintim, H.Y.; Bary, A.; Hayes, D.; Wadsworth, L.; Anunciado, M.; English, M.; Bandopadhyay, S.; Schaeffer, S.; DeBruyn, J.; Miles, C.; et al. In Situ degradation of biodegradable plastic mulch films in compost and agricultural soils. Sci. Total Environ. 2020, 727, 138668. [CrossRef]

41. Karamanlioglu, M.; Robson, G.D. The influence of biotic and abiotic factors on the rate of degradation of poly(lactic) acid (PLA) coupons buried in compost and soil. Polym. Degrad. Stab. 2013, 98, 2063-2071. [CrossRef]

42. Weng, Y.X.; Wang, L.; Zhang, M.; Wang, X.L.; Wang, Y.Z. Biodegradation behavior of P(3HB,4HB)/PLA blends in real soil environments. Polym. Test. 2013, 32, 60-70. [CrossRef]

43. Kale, G.; Kijchavengkul, T.; Auras, R.; Rubino, M.; Selke, S.E.; Singh, S.P. Compostability of bioplastic packaging materials: An overview. Macromol. Biosci. 2007, 7, 255-277. [CrossRef] [PubMed]

44. Rudnik, E.; Briassoulis, D. Comparative biodegradation in soil behavior of two biodegradable polymers based on renewable resources. J. Polym. Environ. 2011, 19, 18-39. [CrossRef]

45. Rudnik, E.; Briassoulis, D. Degradation behavior of poly(lactic acid) films and fibers in soil under Mediterranean field conditions and laboratory simulations testing. Ind. Cros. Prod. 2011, 33, 648-658. [CrossRef]

46. Kijchavengkul, T.; Auras, R.; Rubino, M.; Selke, S.; Ngouajio, M.; Fernandez, R.T. Biodegradation and hydrolysis rate of aliphatic aromatic polyesters. Polym. Degr. Stab. 2010, 95, 2641-2647. [CrossRef]

47. Müller, R.J.; Kleeberg, I.; Deckwer, W.D. Biodegradation of polyesters containing aromatic constituents. J. Biotech. 2001, 86, 87-95. [CrossRef]

48. Saadi, Z.; Cesar, G.; Bewa, H. Fungal degradation of poly(butylene adipate-co-terephthalate) in soil, and in compost. J. Polym. Environ. 2013, 21, 893-901. [CrossRef]

49. Jarerat, A.; Tokiwa, Y.; Tanaka, H. Production of poly(L-lactide)-degrading enzyme by Amycolatopsis orientalis for biological recycling of poly(L-lactide). Appl. Microbiol. Biotechnol. 2006, 72, 726-731. [CrossRef]

50. Mellon, J.E.; Cotty, P.J.; Dowd, M.K. Aspergillus flavus hydrolases: Their roles in pathogenesis and substrate utilization. Appl. Microbiol. Biotechnol. 2007, 77, 497-504. [CrossRef]

51. Moore-Kucera, J.; Karich, K.; Inglis, D.A.; Miles, C.; Kinloch, K.; Bailes, G.; Brodhagen, M. Native soil fungi associated with compostable plastics in three contrasting agricultural settings. Appl. Microbiol. Biotechnol. 2014, 98, 6467-6485. [CrossRef]

52. Li, Q.; Ning, P.; Zheng, L.; Huang, J.; Li, G.; Hsiang, T. Fumigant activity of volatiles of Streptomyces globisporus JK-1 against Penicillium italicum on Citrus microcarpa. Postharvest Biol. Technol. 2010, 58, 157-165. [CrossRef]

53. DeVetter, L.W.; Watkinson, S.; Zasada, I.A.; Weiland, J.E.; Hesse, C.; Walters, T.W. Effectiveness of nontarped broadcast fumigation and root removal on root lesion nematode and Fusarium and Pythium species in a red raspberry system. Plant Health Prog. 2018, 19, 168-175. [CrossRef]

54. Rudolph, R.E.; Zasada, I.A.; Hesse, C.; DeVetter, L.W. Brassicaceous seed meal, root removal, and chemical fumigation vary in their effects on soil quality parameters and Pratylenchus penetrans in a replanted floricane raspberry production system. Appl. Soil Ecol. 2019, 133, 44-51. [CrossRef]

(C) 2020 by the authors. Licensee MDPI, Basel, Switzerland. This article is an open access article distributed under the terms and conditions of the Creative Commons Attribution (CC BY) license (http://creativecommons.org/licenses/by/4.0/). 